\title{
The consensus land plant chloroplast gene order is present, with two alterations, in the moss Physcomitrella patens
}

\author{
Patrick J. Calie * and Karen W. Hughes \\ Department of Botany, University of Tennessee, Knoxville, TN 37996-1100, USA
}

\begin{abstract}
Summary. A restriction endonuclease cleavage site map for the enzymes $C l a \mathrm{I}$ and $B g l \mathrm{II}$, and a partial map for $S a c \mathrm{I}$, has been constructed for the chloroplast genome of the moss Physcomitrella patens (Hedw.) BSG. The plastid chromosome contains approximately $122 \mathrm{~kb}$ organized into small $(21 \mathrm{~kb})$ and large $(82 \mathrm{~kb})$ single-copy regions separated by two copies of a repeat sequence $(9.4 \mathrm{~kb})$ oriented in an inverted arrangement. Genes for 17 proteins and 2 ribosomal RNAs have been mapped using heterologous probes from corn, spinach, pea, and petunia. The general order and arrangement of the moss chloroplast genes are similar to the consensus land plant genome typified by that of spinach, with two major exceptions. First, there is an inversion of approximately $20 \mathrm{~kb}$, bordered internally by $p s b A$ and $a t p H$, and also containing the genes atpF and atp $A$. Second, $r p / 2$ and $r p s 19$ have been relocated to a different position within the large single-copy region, adjacent to the $20 \mathrm{~kb}$ inversion.
\end{abstract}

Key words: Moss chloroplast DNA - Restriction/gene map

\section{Introduction}

Various structural aspects of the chloroplast genome have been elucidated in over 200 angiosperm taxa (reviewed in Bedbrook and Kolodner 1979; Wallace 1982; Whitfeld and Bottomley 1983; Crouse et al. 1985; Palmer 1985). Angiosperm chloroplast DNAs are circular, range in size from $120 \mathrm{~kb}$ to $217 \mathrm{~kb}$, and with two exceptions are organized into two single copy regions of approximately $20 \mathrm{~kb}$ and $80 \mathrm{~kb}$, separated by two inverted repeat regions (each containing a complete set of ribosomal RNA genes) ranging in size from $10 \mathrm{~kb}$ to $76 \mathrm{~kb}$ (Palmer 1985). The chloroplast genomes from the legumes broad bean (Vicia faba) and pea (Pisum sativum) lack the inverted repeats (Chu et al. 1981; Palmer and Thompson 1981; Kolodner and Tewari 1975; Köller and Delius 1980). Those chloroplast genomes that contain the inverted repeats exhibit a highly conserved linear order of common sequence elements (Fluhr and Edelman 1981a; Palmer and Thomson 1982; De Heij et al. 1983; reviewed in Palmer 1985). This observation has led

* Present address: Department of Biology, University of Michigan, Ann Arbor, MI 48109-1048, USA

Offprint requests to: P.J. Calie to the emergence of a consensus angiosperm chloroplast gene order, typified by that of spinach (Spinacia oleracea) (Palmer 1985). Exceptions to this consensus are of two types. The most drastic deviation is found in the chloroplast genomes of mung bean and pea, which exhibit numerous and extensive sequence rearrangements scattered through-

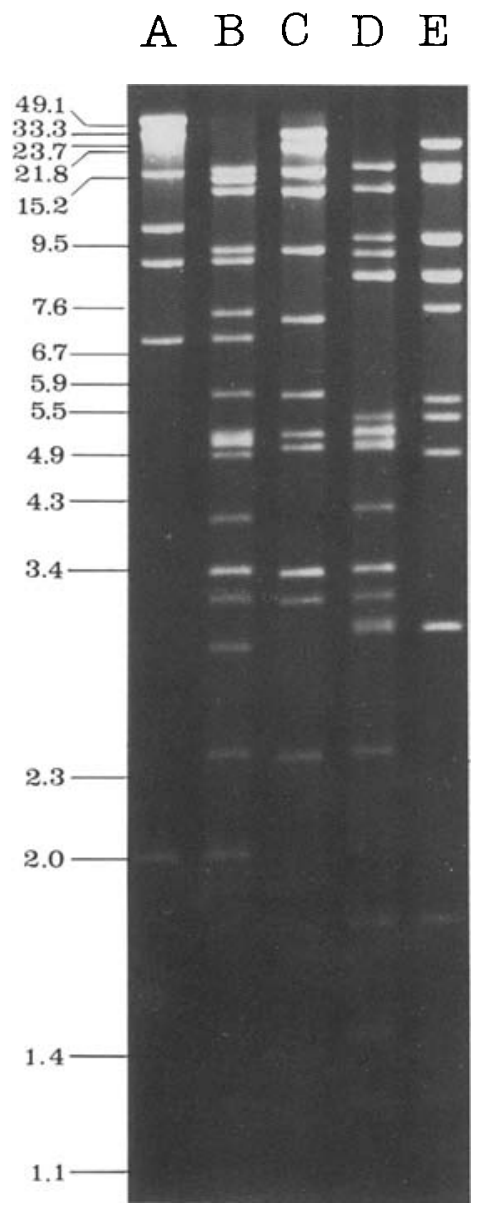

Fig. 1. Single and double digestion products of Physcomitrella patens chloroplast DNA with the following restriction endonucleases: Lane A SacI; lane B, SacI/ClaI; lane C, ClaI; lane D, ClaI/BglII; lane E, $B g / I$ I. Fragment sizes were determined by co-electrophoresis with a range of phage $\lambda$ DNA fragments produced by separate digestions with HindIII, EcoRI and SalI, as well as undigested phage $\lambda$ DNA. Molecular weight sizes are listed in kilobases along the left ordinate 
Table 1. Molecular sizes of Physcomitrella patens chloroplast DNA fragments produced by digestion with restriction endonucleases ${ }^{a}$

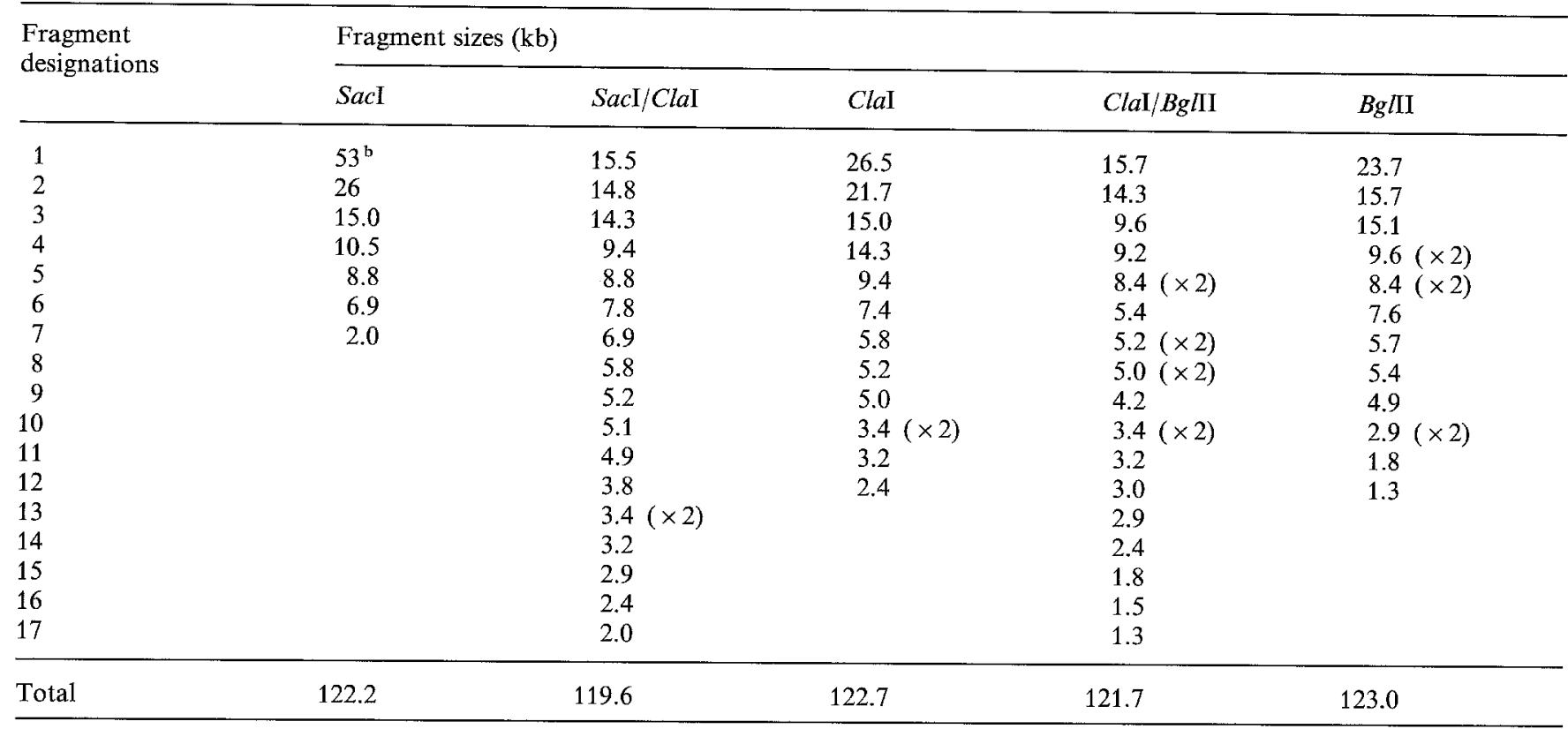

a Fragments smaller than $1 \mathrm{~kb}$ were not measured

${ }^{b}$ Determined by summation of sizes of sub-fragments produced by digestion with a second restriction endonuclease

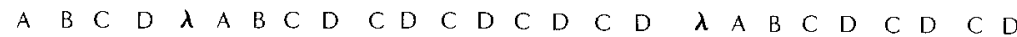

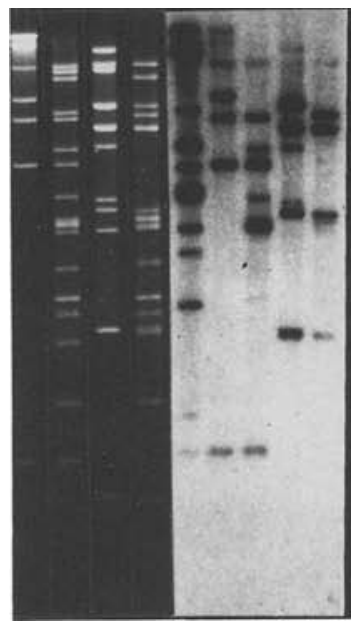

1

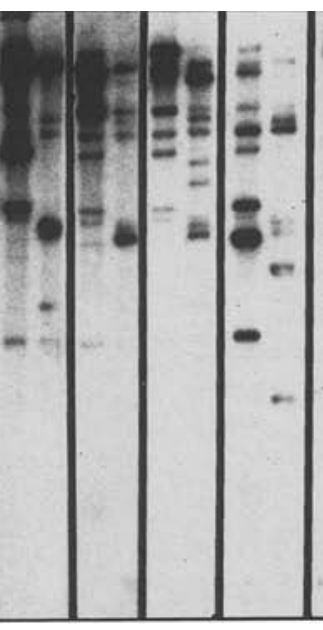

$2 \quad 3 \quad 4 \quad 5$

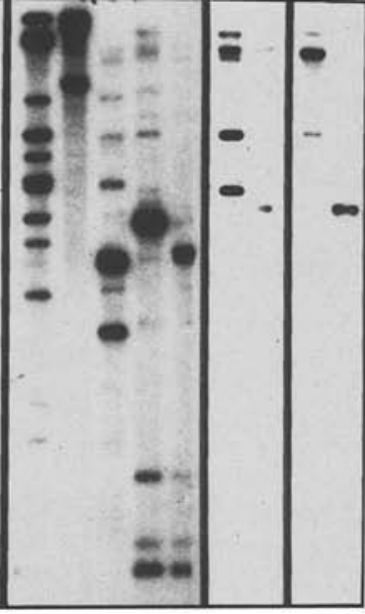

6
$A$ B C D C
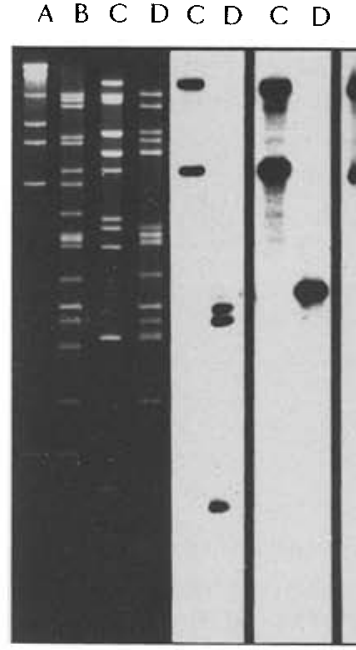

$9 \quad 10 \quad 11$

\section{$\lambda$ A B C D}

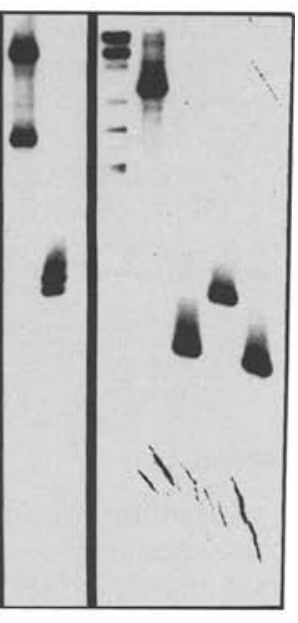

12

Fig. 2. Results of hybridizations with Physcomitrella patens radiolabeled ClaI chloroplast DNA fragments to chloroplast DNA digested by A, SacI; B, SacI/ClaI; C, BglII; D, BglII/ClaI. Numbers below the lanes refer to the specific ClaI fragments (Table 1) used as hybridization probes. Reference markers of phage $\lambda$ DNA digested with EcoRI and HindIII, as well as intact phage $\lambda$ DNA, are in lanes marked $\lambda$

out the chloroplast genome (Palmer and Thompson 1982). Several chloroplast genomes with the inverted repeat exhibit more restricted rearrangements, the result of one or two inversion events (Palmer and Thompson 1982; Palmer et al. 1983; Courtice et al. 1985; Hirai et al. 1985; Tyagi and Herrmann 1986; Jansen and Palmer 1987).

Structural analyses of chloroplast DNAs from non-angiosperm land plants have extended our understanding of the tempo and mode of structural evolution in the chloroplast genome. The chloroplast DNAs of three species in the pteridophyte genus Osmunda are highly conserved in sequence arrangement, and closely resemble the consensus angiosperm chloroplast genome (Stein et al. 1986). Furthermore, the structure and arrangement of DNA sequences are highly conserved among Osmunda cinnamomea, the gymnosperm Ginkgo biloba, and the angiosperms petunia (Petunia hybrida) and mung bean (Vigna radiata) (Palmer and Stein 1986). Even more remarkable is the demonstration that the chloroplast genomes of the liverwort Marchantia polymorpha (Ohyama et al. 1986) and the angiosperm tobacco (Nicotiana tabacum) (Shinozaki et al. 1986) are almost identical with respect to the organization of over 120 genes, despite their evolutionary distance and their genome size differences (121 kb versus $156 \mathrm{~kb}$, respectively). 
Table 2. Summary of restriction fragment mapping hybridization data

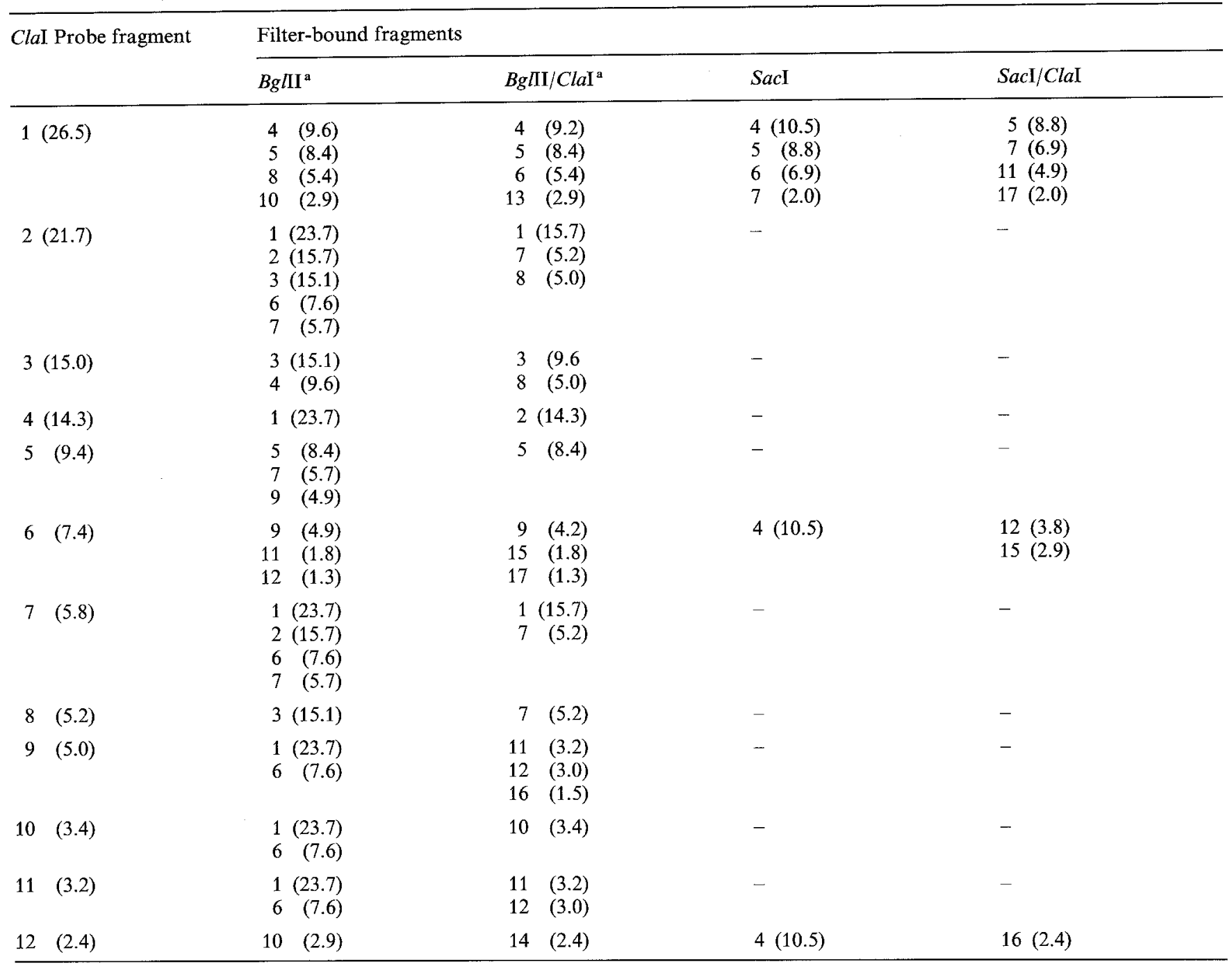

Hybridization signals due to artifact or contamination are excluded. Fragment designations are as in Table 1; molecular weights in $\mathbf{k b}$ pairs are listed in parenthesis

a Based on data from replicate experiments (Calie 1986)

Thus the gross structure of the chloroplast genome appears to be highly conserved in those characterized taxa representing diverse evolutionary lineages of land plants.

To expand further our understanding of non-angiosperm chloroplast genomes we undertook the characterization of the chloroplast genome of a moss. A map of Physcomitrella patens chloroplast DNA has been constructed, showing the locations of recognition sites for the restriction endonucleases $B g l \mathrm{II}, C l a \mathrm{I}$, and $S a c \mathrm{I}$, and the approximate positions of two ribosomal RNA (rRNA) and 17 proteinencoding genes have been determined.

\section{Materials and methods}

Isolation of DNA and restriction endonuclease analysis. Chloroplast DNA was isolated and purified from moss gametophyte tissues as described (Calie and Hughes 1987). Plasmid DNAs were isolated by the alkaline lysis method of Birnboim and Doly (1979).

Chloroplast DNA was digested with restriction endonu- cleases under conditions prescribed by the supplier (New England BioLabs, Beverly, MA). Analytical digests were electrophoresed through $0.7 \%$ horizontal agarose gels $(20 \times 25 \times 0.4 \mathrm{~cm})$ in TBE buffer (Maniatis et al. 1982).

${ }^{32} P$ Radiolabeling of $D N A$. Chloroplast DNA restriction fragments, generated by $C l a I$, were labeled with ${ }^{32} \mathrm{P}$ at the 3' termini as described (Calie 1986). Plasmid DNA restriction fragments containing chloroplast rRNA gene probes were radiolabeled with ${ }^{32} \mathrm{P}$ by a nick-translation reaction without DNaseI (Maniatis et al. 1975). Plasmid DNAs containing the other chloroplast gene probes were also labeled with a nick-translation reaction with DNaseI (Davis et al. 1980).

Radiolabeled restriction fragments were fractionated on either $0.4 \%$ or $1 \%$ low melting temperature agarose gels and prepared for hybridization to filter-bound chloroplast DNA digests as described (Palmer 1986). Nick-translated plasmid DNAs were purified and prepared for hybridization as described (Davis et al. 1980). 
Table 3. Descriptions of gene probes

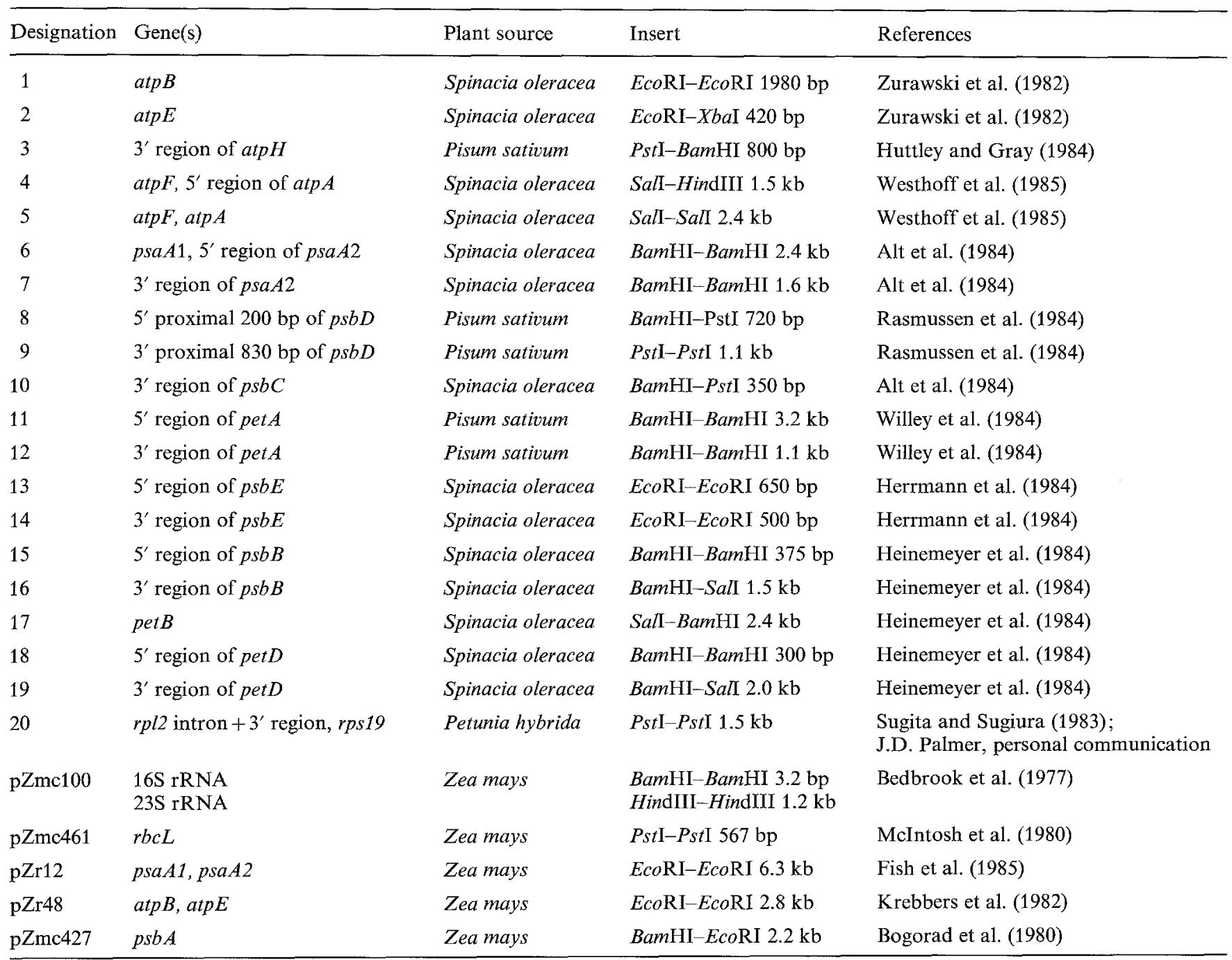

Transfer of DNA to nitrocellulose filters/hybridization to radiolabeled probes. Gel-fractionated analytical chloroplast DNA digests were transferred to nitrocellulose filters in a bidirectional manner (Smith and Summers 1980). Prehybridization and hybridization conditions were as described (Meinkoth and Wahl 1984). Nitrocullulose filters were washed and autoradiography of hybridized filters was performed under standard conditions (Maniatis et al. 1982).

\section{Results and Discussion}

\section{Restriction fragment mapping}

Physcomitrella patens chloroplast DNA was digested to completion with the restriction endonucleases $C l a \mathrm{I}, B g I \mathrm{II}$, and SacI. Summation of restriction fragment sizes, taking into account fragment stoichiometries, indicates a genome size of $122 \mathrm{~kb}$ (Fig. 1, Table 1).

Restriction endonuclease cleavage sites were mapped by the following principles. A set of chloroplast DNA restriction fragments (e.g. generated by $C l a I$ ) were radiolabeled and then fractionated by gel electrophoresis. The separated fragments were then used as hybridization probes against filter-bound chloroplast DNA digests generated by $\mathrm{ClaI}$,
$B g l \mathrm{II}, S a c \mathrm{I}, B g l \mathrm{II} / \dot{C} l a \mathrm{I}$, and SacI/ClaI. Hybridizations to single digests generated overlaps between probe and filterbound fragments. Hybridizations to the double digests yielded the precise locations of cleavage sites within the probe fragments (Palmer 1982, 1986). These data are illustrated in Fig. 2 and summarized in Table 2. Self-hybridizations of probe fragments to chloroplast DNA digests generated by the same enzyme (i.e. ClaI) revealed the presence of reiterated sequences within the probe fragments (Fluhr and Edelman $1981 \mathrm{~b}$ ). Hybridizations with defined gene probes resolved mapping ambiguities due to either crosscontamination of restriction fragment probes, or difficulties in establishing the order of the smaller restriction fragments (Spielmann et al. 1983).

\section{The inverted repeat}

The inverted repeat has a minimum size of $3.4 \mathrm{~kb}$ (the doublet fragment Cla 10), and a maximum size of $12.4 \mathrm{~kb}$ [Cla 10 $(3.4 \mathrm{~kb})+$ Cla $7(5.8 \mathrm{~kb})+C l a 11(3.2 \mathrm{~kb})]$. The actual size of the inverted repeat was estimated by comparing the autoradiographic intensities of cross- and self-hybridizing fragments located at the termini of the repeats (Palmer and Stein 1986). Cla 7 (5.8 kb), located at the upper right end 


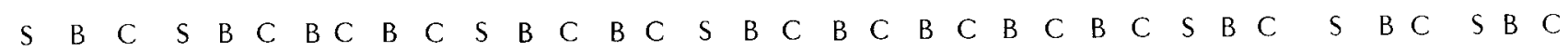

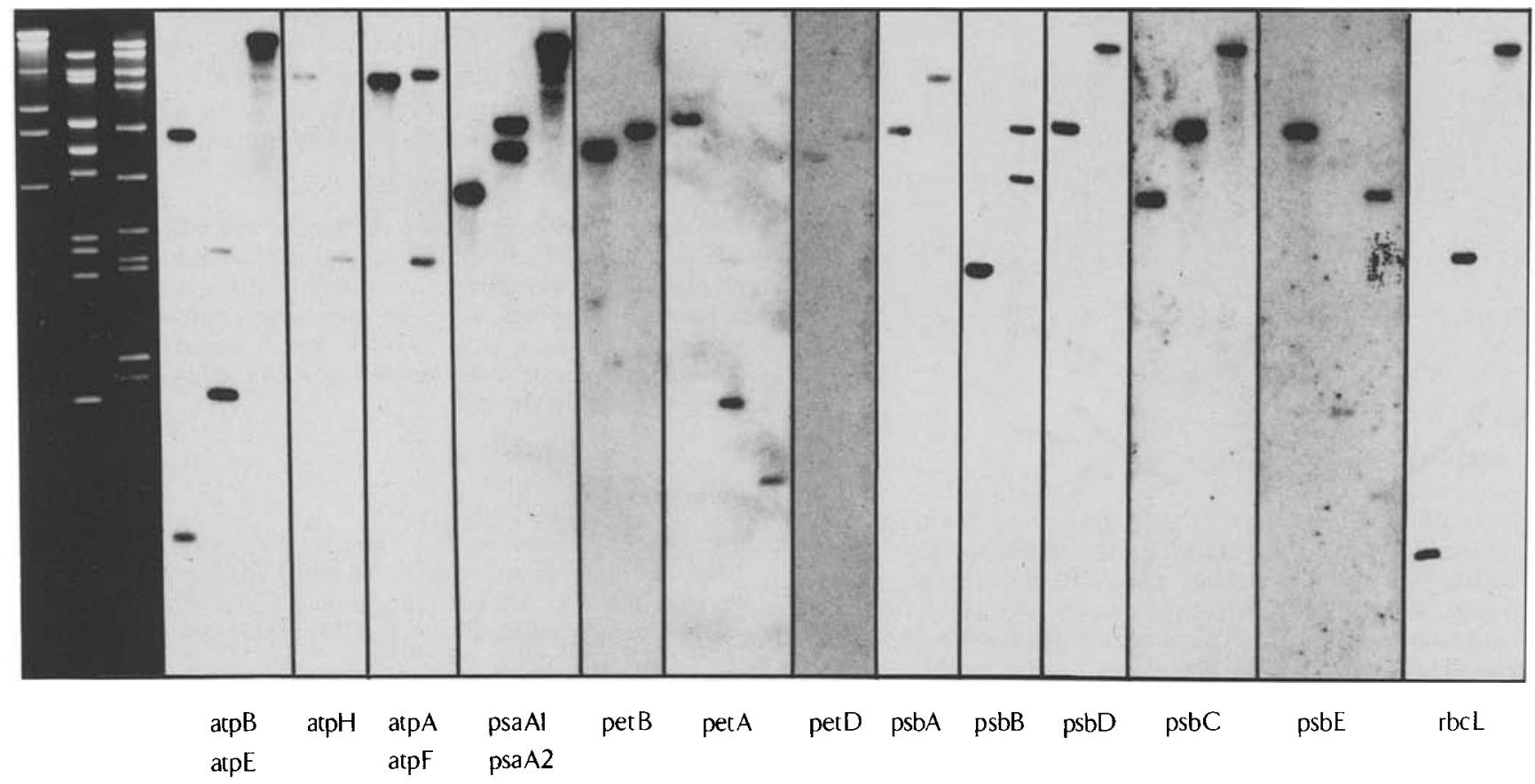

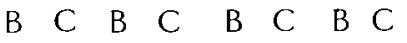

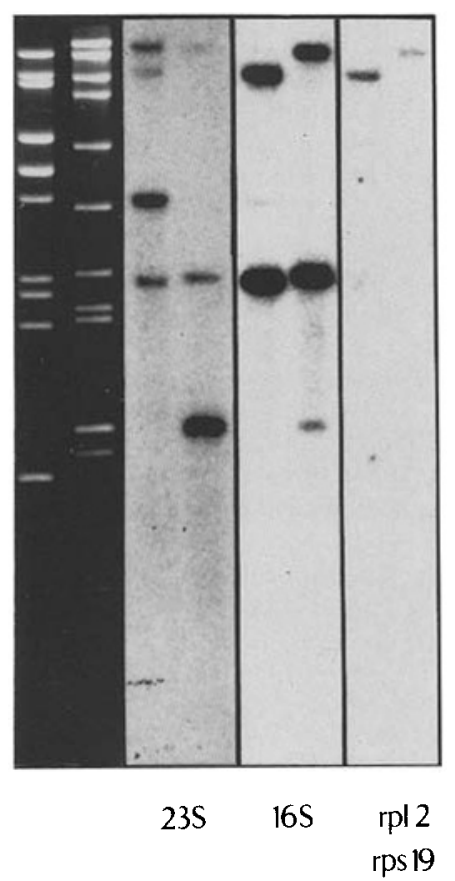

Fig. 3. Gene mapping hybridizations with Physcomitrella patens chloroplast DNA digested with: S, SacI; C, ClaI; B, BglII. Specific gene probes used in hybridizations are indicated by acronym (Table 3 ) below the respective autoradiogram. Probes that encompassed different regions of the same gene (Table 3 ) were combined in a single hybridization experiment

of the repeat, hybridized approximately half as strongly to $C l a 2(21.7 \mathrm{~kb})$ as to itself. Similarly, Cla $11(3.2 \mathrm{~kb})$, located at the lower left end of the repeat, produced a hybridization signal of almost equal intensity to Cla $9(5.0 \mathrm{~kb})$ as to itself (Calie 1986). We estimate that the repeats extend approximately $3 \mathrm{~kb}$ into $\mathrm{Cla} 7$ and $\mathrm{Cla} 2$, and $3 \mathrm{~kb}$ into Cla 11 and Cla 9 . The actual size of each copy of the inverted repeat is estimated to be $9.4 \mathrm{~kb}$.

The universal arrangement of rRNA genes within the inverted repeat, i.e. the $23 \mathrm{~S}$ rRNA gene proximal to and the $16 \mathrm{~S}$ gene distal to the small single copy region, is present in the moss chloroplast genome. These were the only genes found within the inverted repeat region using the probes listed in Table 2.

\section{Gene mapping}

Results of hybridizations with defined chloroplast gene probes (Table 3) from three dicots (spinach, petunia, and pea) and one monocot (maize) to moss chloroplast DNA digests are illustrated in Fig. 3. The composite restriction site and gene map is shown in Fig. 4.

As gene probes $2,5,10, \mathrm{pZmc} 461$, and the $1.2 \mathrm{~kb}$ BamHI subfragment from pZmc100 contain only specific 


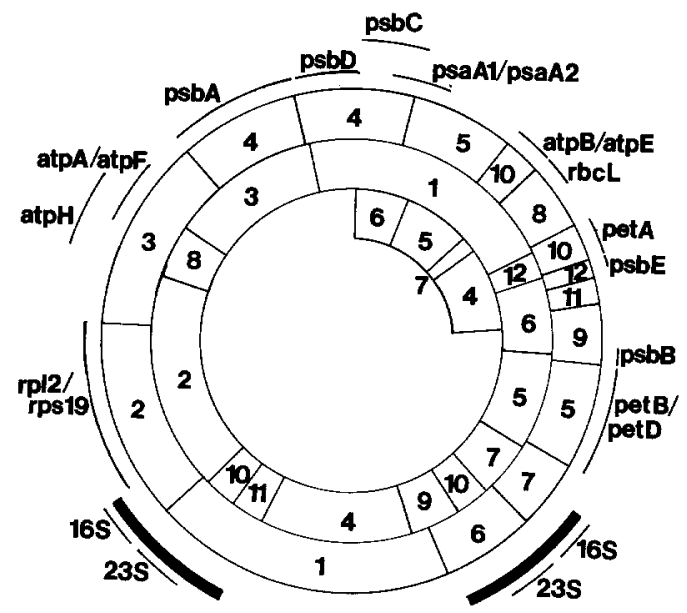

Fig. 4. Physical and gene map of the Physcomitrella patens chloroplast genome. BglII sites are shown on the outermost circle, ClaI sites on the complete inner circle, and SacI sites on the partial inner circle. Restriction fragment designations are as in Table 1 , gene acronyms as in Table 3 . The estimated extent of the inverted repeat is indicated by the two filled lines parallel to the circular map

gene sequences, hybridization between these chloroplast gene probes and moss chloroplast DNA restriction fragments must be due to actual homology between the angiosperm and the moss genes. Probes 1, 3, 4, 6-9, 11-20, $\mathrm{pZr} 48, \mathrm{pZr12}$, and $\mathrm{pZmc427}$ and the $3.2 \mathrm{~kb}$ HindIII subfragment from pZmc100 contain flanking sequences in addition to specific chloroplast genes. We cannot exclude the possibility that the hybridization with these probes is due to homologies that lie outside the regions containing the gene-specific sequences.

The most significant finding of this investigation is that the moss chloroplast genome contains a gene order similar to the consensus land plant chloroplast genome. Thus the majority of the chloroplast genes have been conserved in order and arrangement since the divergence of the moss lineage from the other land plant lineages approximately 345-375 MYA (Scagel et al. 1982; Schofield 1985).

The deviations in the moss chloroplast gene order from the consensus land plant gene order are quite notable. The first involves an exchange of the positions of atpH and $p s b A$. The second is the relocation of $r p l 2$ and rps 19 from a position adjacent to the petB/pet $D$ gene cluster to a locus flanking atp $H$. The first situation is clearly due to an inversion of a $20 \mathrm{~kb}$ region, resulting in a reorientation of $p s b A$ and $\operatorname{atp} H$ (atp $A$ and $a t p F$ are also present within this inversion, but our mapping data do not allow for a precise evaluation of the repositioning of these two genes). The second situation is also probably due to an inversion involving the region encompassing both inverted repeats, flanking portions of the large single-copy region, and the small single-copy region. Inversion events within chloroplast genomes are not without precedent, and are found in a number of land plant taxa (reviewed in Palmer 1985). Significantly, the liverwort Marchantia polymorpha, a representative of the land plant lineage that has the nearest phylogenetic affinity to the mosses (Mishler and Churchill 1984) contains an inversion similar to the atpH/psbA inversion found in the moss chloroplast genome.

In summary, the chloroplast genome of the moss Phys- comitrella patens contains a gene order which reflects the consensus land plant chloroplast gene arrangement with the exception of two rearrangement events. Thus, although rearrangements are evident in some chloroplast DNAs, the land plant chloroplast genome appears to be a highly conserved system, evolving at a very slow rate on a gross structural level.

Acknowledgements. Appreciation is extended to Dr. Lawrence Bogorad and Dr. Jeff Palmer for their gifts of defined chloroplast gene probes and their advice and interest in this project; to Dr. Jeff Palmer for his review of the manuscript; and to K.K. Clevenger, J.T. Dermody, N.S. Fredrick, and P. Kimmons for their technical assistance. PJC is a recipient of a University of Tennessee Science Alliance Fellowship.

\section{References}

Alt J, Morris J, Westhoff P, Herrmann RG (1984) Nucleotide sequence of the clustered genes for the $44 \mathrm{kd}$ chlorophyll-a apoprotein and the " $32 \mathrm{kd}$ " like protein of the Photosystem II reaction center in the spinach plastid chromosome. Curr Genet 8:597-606

Bedbrook JR, Kolodner R (1979) The structure of chloroplast DNA. Annu Rev Plant Physiol 30:593-620

Bedbrook JR, Kolodner R, Bogorad L (1977) Zea mays chloroplast ribosomal RNA genes are part of a 22,000 base-pair inverted repeat. Cell 11:739-749

Birnboim HC, Doly J (1979) A rapid alkaline extraction procedure for screening recombinant plasmid DNA. Nucleic Acids Res $7: 1513-1523$

Bogorad L, Jolly SO, Kidd G, Link G, McIntosh L (1980) Organization and transcription of maize chloroplast genes. In: Leaver CJ (ed) Genome Organization and Expression in Plants. NATO Advanced Study Institute Series A, Vol 29, Plenum Press, NY, pp 291-304

Calie PJ (1986) A molecular characterization of the chloroplast genome of the moss Physcomitrella patens. Ph.D. thesis, University of Tennessee, Knoxville

Calie PJ, Hughes KW (1986) An efficient protocol for the isolation and purification of chloroplast DNA from moss gametophyte tissues. Plant Mol Biol Rep 4:206-212

Chu NM, Oishi KK, Tewari KK (1981) Physical mapping of the pea chloroplast DNA and localization of the ribosomal RNA genes. Plasmid 6:279-292

Courtice GRM, Bowman CM, Dyer TA, Gray JC (1985) Localisation of genes for components of Photosystem II in chloroplast DNA from pea and wheat. Curr Genet 10:329-333

Crouse EJ, Schmitt JM, Bohnert HJ (1985) Chloroplast and cyanobacterial genomes, genes and RNAs: a compilation. Plant Mol Biol Rep 3:43-89

Davis RW, Botstein D, Roth JR (1980) Advanced Bacterial Genetics. An Experimental Approach. Cold Spring Harbor Laboratory, Cold Spring Harbor, New York

DeHeij HT, Lustig H, Moeskops DJM, Bovenberg WA, Bisanz C, Groot GSP (1983) Chloroplast DNAs of Spinacia, Petunia, and Spirodela have a similar gene organization. Curr Genet $7: 1-6$

Fish LE, Kück U, Bogorad L (1985) Two partially homologous adjacent light-inducible maize chloroplast genes endoding polypeptides of the P700 chlorophyll-a protein complex of Photosystem I. J Biol Chem 260:1413-1421

Fluhr R, Edelman M (1981 a) Conservation of sequence arrangements among higher plant chloroplast DNAs: molecular crosshybridization among the Solanaceae and between Nicotiana and Spinacia. Nucleic Acids Res 9:6841-6853

Fluhr R, Edelman M (1981 b) Physical mapping of Nicotiana tabacum chloroplast DNA. Mol Gen Genet 181:484-490

Heinemeyer W, Alt J, Herrmann RG (1984) Nucleotide sequence of the clustered genes for apocytochrome $b_{6}$ and subunit 4 of 
the cytochrome $b / f$ complex in the spinach plastid chromosome. Curr Genet 8:543-549

Herrmann RG, Alt J, Schiller B, Widger WR, Cramer WA (1984) Nucleotide sequence of the gene for apocytochrome $b_{559}$ on the spinach plastid chromosome: implications for the structure of the membrane protein. FEBS Lett 176:239-244

Hirai A, Ishibashi T, Morikami N, Iwatsuki N, Shinozaki K, Sugiura $M$ (1985) Rice chloroplast DNA: a physical map and location of the genes for the large subunit of ribulose-1,5-phosphate carboxylase and the $32 \mathrm{kd}$ Photosystem II reaction center protein. Theor Appl Genet 70:117-122

Huttly AK, Gray JC (1984) Localization of genes for four ATP synthase subunits in pea chloroplast DNA. Mol Gen Genet 194:402-409

Jansen RK, Palmer JD (1987) Chloroplast DNA from lettuce and Barnadesia (Asteraceae): structure, gene localization, and characterization of a large inversion. Curr Genet 11:553-564

Köller B, Delius H (1980) Vicia faba chloroplast DNA has only one set of ribosomal RNA genes as shown by partial denaturation mapping and R-loop analysis. Mol Gen Genet 178:261-269

Kolodner R, Tewari KK (1975) The molecular size and conformation of the chloroplast DNA from higher plants. Biochim Biophys Acta 402:372-390

Krebbers ET, Larrinua IM, McIntosh L, Bogorad L (1982) The maize chloroplast genes for the $\beta$ and $\varepsilon$ subunits of the photosynthetic coupling factor $\mathrm{CF}_{\mathrm{X}}$ are fused. Nucleic Acids Res $10: 4985-5002$

Maniatis T, Jeffrey A, Kleid DG (1975) Nucleotide sequence of the rightward operator of phage $\lambda$. Proc Natl Acad Sci USA 72:1184-1188

Maniatis T, Fritsch EF, Sambrook J (1982) Molecular Cloning: A Laboratory Manual. Cold Spring Harbor Laboratory, Cold Spring Harbor, New York

McIntosh L, Poulsen C, Bogorad L (1980) Chloroplast gene sequence for the large subunit of ribulose bisphosphate carboxylase of maize. Nature 288:556-560

Meinkoth J, Wahl G (1984) Hybridization of nucleic acids immobilized on solid supports. Anal Biochem 138:267-284

Mishler BD, Churchill SP (1984) A cladistic approach to the phylogeny of the "bryophytes". Brittonia 36:406-424

Ohyama K, Fukuzawa H, Kohchi T, Shirai H, Sano T, Sano S, Umesono K, Shiki Y, Takeuchi M, Chang Z, Aota S, Inokuchi H, Ozeki H (1986) Chloroplast gene organization deduced from complete sequence of liverwort Marchantia polymorpha chloroplast DNA. Nature 322:572-574

Palmer JD (1982) Physical and gene mapping of chloroplast DNA from Atriplex triangularis and Cucumis sativa. Nucleic Acids Res 10:1593-1605

Palmer JD (1985) Comparative organization of chloroplast genomes. Annu Rev Genet 19:325-354

Palmer JD (1986) Isolation and structural analysis of chloroplast DNA. Methods Enzymol 118:167-186

Palmer JD, Stein DB (1986) Conservation of chloroplast genome structure among vascular plants. Curr Genet 10:823-833

Palmer JD, Thompson WF (1981) Rearrangements in the chloroplast genomes of mung bean and pea. Proc Natl Acad Sci USA $78: 5533-5537$

Palmer JD, Thompson WF (1982) Chloroplast DNA rearrange- ments are more frequent when a large inverted repeat sequence is lost. Cell 29:537-550

Palmer JD, Singh GP, Pillay DTN (1983) Structure and sequence evolution of three legume chloroplast DNAs. Mol Gen Genet 190:13-19

Rasmussen OF, Bookjans G, Stummann BM, Henningsen KW (1984) Localization and nucleotide sequence of the gene for the membrane polypeptide D2 from pea chloroplast DNA. Plant Mol Biol 3:191-199

Scagel RF, Bandoni RJ, Maze JR, Rouse GE, Schofield WB, Stein JR (1982) Nonvascular Plants: An Evolutionary Survey. Wadsworth Publ Co, Belmont, CA

Schofield WB (1985) Introduction to Bryology. Macmillan, NY

Shinozaki K, Ohme M, Tanaka M, Wakagusi T, Hayashida N, Matsubayashi T, Zaita N, Chunwongse J, Obokata J, Yamaguchi-Shinozaki K, Ohto C, Torasawa K, Meng BY, Sugita M, Deno H, Kamogashira T, Yamada K, Kusuda J, Takaiwa F, Kato A, Tohdoh N, Shimada H, Sugiura M (1986) The complete nucleotide sequence of the tobacco chloroplast genome: its gene order and expression. EMBO J 5:2043-2049

Smith GE, Summers MD (1980) The bidirectional transfer of DNA and RNA to nitrocellulose or diazobenzyloxymethyl-paper. Anal Biochem 109:123-129

Spielmann A, Ortiz W, Stutz E (1983) The soybean chloroplast genome: construction of a circular restriction site map and location of DNA regions encoding the genes for the rRNAs, the large subunit of the ribulose-1,5-biphosphate carboxylase and the $32 \mathrm{kd}$ protein of the Photosystem II reaction center. Mol Gen Genet 190:5-12

Stein DB, Palmer JD, Thompson WF (1986) Structural evolution and flip-flop recombination of chloroplast DNA in the fern genus Osmunda. Curr Genet 10:835-841

Sugita M, Sugiura M (1983) A putative gene of tobacco chloroplast coding for ribosomal protein similar to $E$. coli ribosomal protein S19. Nucleic Acids Res 11:1913-1918

Tyagi AK, Herrmann RG (1986) Location and nucleotide sequence of the pre-apocytochrome $f$ gene on the Oenothera hookeri plastid chromosome (Euoenothera plastome I). Curr Genet $10: 481-486$

Wallace DC (1982) Structure and evolution of organelle genomes. Microbiol Rev 46:208-240

Westhoff P, Alt J, Nelson N, Herrmann RG (1985) Genes and transcripts for the ATP synthase $\mathrm{CF}_{0}$ subunits I and II from spinach thylakoid membranes. Mol Gen Genet 199:290-299

Whitfeld PR, Bottomley W (1983) Organization and structure of chloroplast genomes. Annu Rev Plant Physiol 34:279-310

Willey DL, Howe CJ, Auffret AD, Bowman CM, Dyer TA, Gray JC (1984) Location and nucleotide sequence of the gene for cytochrome $\mathrm{f}$ in wheat chloroplast DNA. Mol Gen Genet 194:416-422

Zurawski G, Bottomley W, Whitfeld PR (1982) Structures of the genes for the $\beta$ and $\varepsilon$ subunits of spinach chloroplast ATPase indicate a dicistronic mRNA and an overlapping translation stop/start signal. Proc Natl Acad Sci USA 79:6260 6264

Communicated by R.G. Herrmann

Received November 10, 1986 